\title{
金属材料の抗菌性
}

\section{Antibacterial Effect of Metal Materials}

\section{佐 藤 嘉 洋*}

Yoshihiro SATO

Key Words: Bacteria, Biofilm, Antibacterial Metal Materials, Microbiologically Influenced Corrosion

\section{1.はじめに}

我々の身の周りには多くの抗菌製品が溢れているように 見える。衣類から食器、バス・トイレ製品、洗面台、文房 具にいたるまで多くの製品に「抗菌」の表示を見ることが できる。一時は抗菌ブームとも言われ、いたるものに「抗 菌」の表示が見られたが、最近ではそのような風潮も去り、 必要な部分に必要な抗菌機能が施されてきているように感 じられる。そもそも「抗菌」とは、JIS ${ }^{1)}$ の定義によれば「製 品の表面における細菌の増殖を抑制する状態」であり、微 生物を完全に死滅させる「滅菌」や「殺菌」とは区別して 使われており、明確に定義された用語として理解されてい る。したがって、「抗菌」は製品のイメージや消費者の感 覚に訴えるための情緒的な言葉ではなく、製品の一つの機 能として考えられるべきであろう。最近ではその機能を保 証する表示として、抗菌製品技術協議会によるSIAA（ SelfImposed Authorization for Antimicrobial-article（抗菌製品の自 己認証)）マーク制度がある。これは1999年から実施され ており、2000 年に抗菌加工製品一抗菌性試験方法 · 抗菌効

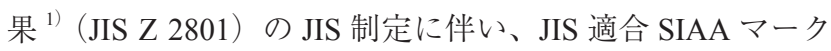
表示されるようになった。また、繊維製品には、抗菌・防臭、 制菌加工として繊維評価技術協議会が認証する SKE マーク が使用されている。「抗菌」機能という考え方は、日本人の 清潔・安全志向から生まれたとも考えられる日本のオリジ ナルブランドでもある。2007 年には抗菌製品技術協議会の 抗菌性評価試験法が ISO で承認され、KOHKIN（抗菌）を あしらったSIAA マークが国際商標になっている。このよ うな事情のもとで多くのプラスチック、セラミックスおよ び繊維等に抗菌処理加工が施され、我々が日常生活で多く の抗菌製品を目にする機会が増えたものと考えられる。

一方、この「抗菌」機能を金属材料に適用しょうとする 試みが行われている。これまでの抗菌機能製品は前述の 如くプラスチック、セラミックスおよび繊維等に多く、金 属材料への適用は限られていた。これは工業用材料として
の金属材料に「抗菌」機能化が必要な部分があることが認 識されてこなかったためであると考えられる。金属材料 の腐食の問題は古くから研究されてきたが、微生物腐食 ${ }^{2)}$ (Microbially Influenced Corrosion: MIC）が一般に認識される ようになったのは近年のことである。微生物腐食とは金属 の腐食に微生物が関与または腐食を促進させる効果を持つ 腐食のことであり、微生物腐食による工場施設・工業製品 の金属材料の損失は甚大であり、年間 $30 \sim 50$ 億ドルにの

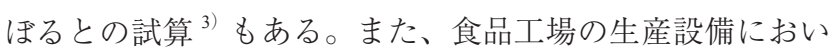
て洗浄が難しい場所で微生物が大量に繁殖し、食品製造機 能が失われてしまう場合もある、このような微生物の影響 が懸念される場合には大量の殺菌剂が使用されるのが通常 であり、殺菌剤の大量投与・廃棄による生態系への悪影響 も心配されている。このような背景の下で日本では、金属 材料の抗菌機能化の研究 ${ }^{4)}$ に対する関心が高くなりつつあ るように思われる。金属材料に抗菌機能を付与することが できれば、このような問題の幾らかは解決できるだろうし、 金属材料にこそ抗菌機能化が必要とされているように思わ れる。本稿では、金属材料の抗菌特性と関連する事項につ いて述べる。

\section{2. 金属材料の抗菌性}

金属元素の幾つかは人体に必須であることはよく知られ ているが、ヒ素やカドミウムのように害毒を及ぼす金属元 素も多く、量が多くなればかなりの金属元素が有害である

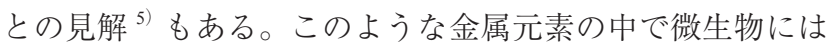
有害であるが、人体には比較的害の少ない金属として銀、 銅、亜鉛等が古くから知られている。特に、銀は無機系抗 菌剤の主剂として用いられており、銅や亜鉛等が副剤とし て添加されている例が多い。無機系抗菌剤はゼオライト、 シリカゲル或いはガラス等の担体にこれらの金属を担持さ せた製品 ${ }^{6)}$ が多く、微粒子粉末や針状結晶として市販され ている。「銀入り」等と書かれたスプレーや抗菌製品には、 このような抗菌剤が添加されている。また、日本では銀や

*大阪市立大学大学院工学研究科（广 558-8585 大阪市住吉区杉本 3-3-138)

Osaka City University (3-3-138 Sugimoto, Sumiyoshi-ku, Osaka, 558-8585, Japan) 


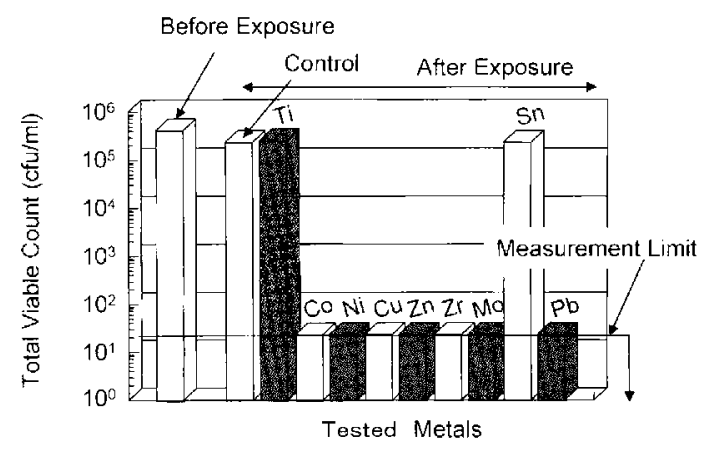

(a)

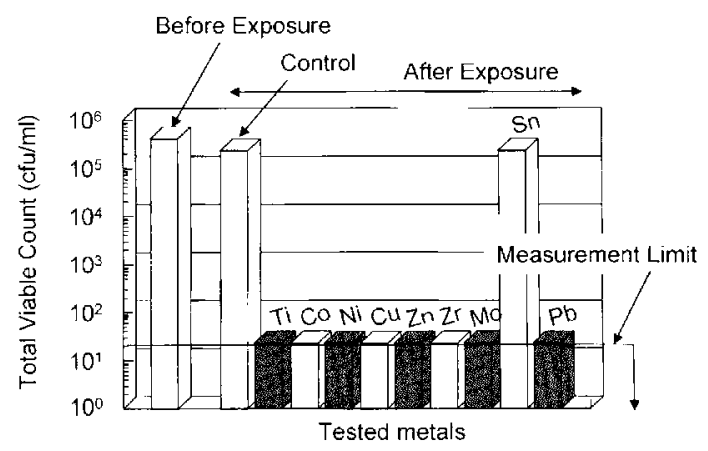

(b)

Fig. 1 Experimental result of contact method. (a) In the case of Staphylococcus aureus (b) In the case of Esherichia coli

銅を添加した抗菌性ステンレス鋼等も開発されてきてい る。しかし、これらの製品の抗菌作用については、未だよ く解っていない部分も多くある。例えば銀の抗菌作用につ いては、幾つかのメカニズムが提案 ${ }^{7)}$ されており、1）銀 の触媒作用により空気中または水中の酸素が活性酸素にな り、微生物に損傷を与える、2）微量の銀イオンが微生物の 細胞表面や内部でタンパク質や酵素等と反応し各種障害を 引き起こし、微生物に損傷を与える、等のように考えられ ている。いずれにしても、抗菌剂として利用されている金 属はごく一部であり、多くの金属の抗菌性は未だ明らかに なっていない。これは統一した抗菌性試験方法が JIS ${ }^{1)}$ とし て定められたのが最近であり、これから評価が本格的に行 われることも一因として考えられる。

一般に抗菌性の試験方法には、フィルム密着法、滴下法 およびシェイク法等がある。フィルム密着法および滴下法 は、調整した菌液を一定時間試料表面に接触させて評価す る方法であり、試験時間中に菌液にフィルムを被せるのが フィルム密着法と呼ばれている。シェイク法は、試料を菌 液中に浸漬して一定時間振とうする方法である。 $\mathrm{JIS}^{1)}$ では 試験結果の再現性、試験操作の簡便性等を考慮して、フィ ルム密着法により試験することが定められている。シェイ ク法については、試験方法の原理が製品の使用方法とかけ 離れている、等の理由のため採用されなかったようである。

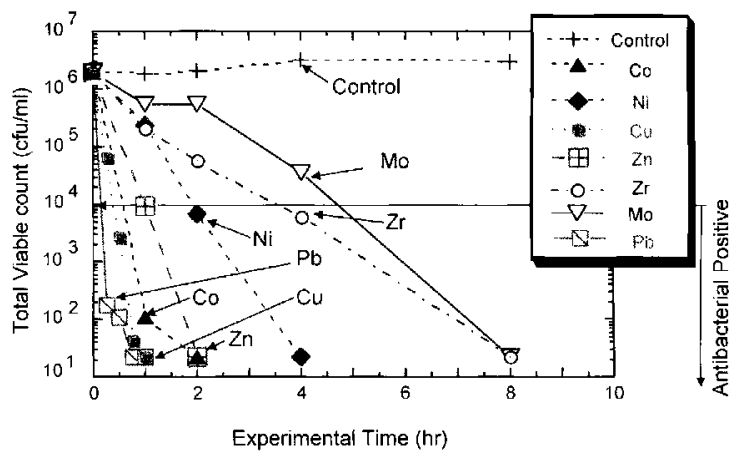

Fig. 2 Valiation of viable bacteria count as a function of experimental time.

$\mathrm{JIS}^{1)}$ のフィルム密着法に基づいて、宮野らは、チタン、 コバルト、ニッケル等の 9 種類の純金属の抗菌性を評価 ${ }^{8)}$ している。Fig. 1 に、この結果を示す。(a)には黄色ブドウ

球菌 (Staphylococcus aureus)、(b)には大腸菌 (Esherichia coli)に対する抗菌性試験結果を示す。JIS ではこの 2 種類 の細胞膜構造の異なる微生物に対して試験することになっ ている。この結果を見ると、(a)の黄色ブドウ球菌の場合に は縦軸に示す生菌数がチタンとスズでは対照 (Control) とほ ぼ同数であり、抗菌性が認められない。他のコバルト、ニッ ケル、銅、悪鉛、ジルコニウム、モリブデンおよび鉛では、 生菌数が対照に比べて 2 桁以上減少しており抗菌性が有る と判定される。JIS では試験片上の菌液の 24 時間後の生菌 数が対照に比べて 2 桁以上減少、即ち生菌の $99 \%$ 以上が死 滅する場合を抗菌性有りと判定している。(b)の大腸菌では、 スズ以外の金属は抗菌性が有ると判定される。チタンは黄 色ブドウ球菌に対しては抗菌性が無く、大腸菌に対しては 抗菌性が有ることになる。これについては、2 種類の微生 物の細胞表層構造の違いより説明されている。JIS では試 験開始 24 時間後の生菌数の変化により抗菌性の有無を判定 するが、これでは 24 時間以内での生菌数の変化が分からな いので、抗菌性が認められる 7 種類の金属について 24 時間 以内での黄色ブドウ球菌に対する生菌数を調べた結果 ${ }^{8)}$ を

Fig. 2 に示す。抗菌性が認められる金属でも生菌数の減少 挙動は異なり、鉛や銅の場合には極短時間で生菌が急激に 減少するのに対し、モリブデンやジルコニウムでは比較的 緩やかに減少している。この減少速度を各金属の殺菌性能 の指標と考えて減少速度を直線近似して、生菌数が $1 / 10$ に なる時間を D 值 (Decimal Reduction Value) として示したの がFig. 3 である。鉛や銅は D 值が小さく抗菌性の高い材料 と考えられ、モリブデンやジルコニウムでは D 值が大きく 比較的抗菌性が低いと考えられる。

同様にフィルム密着法により 21 種類の金属元素について 抗菌性を評価した川上らの結果 ${ }^{9)}$ を Fig.4 に示す。Fig. 4 (a) は試験菌を黄色ブドウ球菌とした場合の結果であり、Fig. 4 (b) は大腸菌での結果である。ここでは 24 時間以内の生 


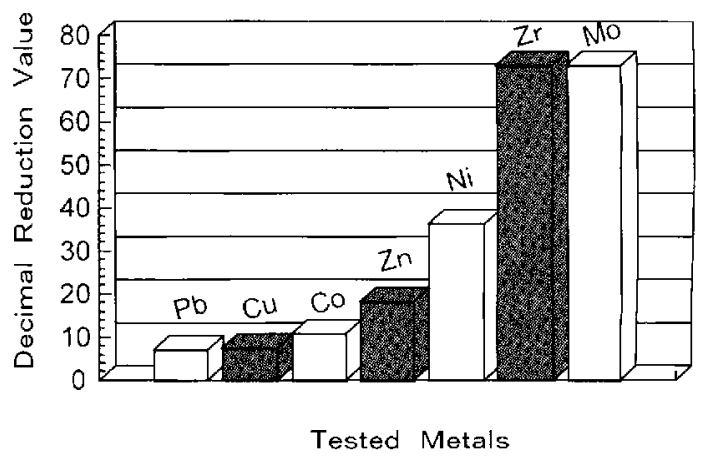

Fig. 3 Decimal reduction value of each tested metals estimated through film contact method.

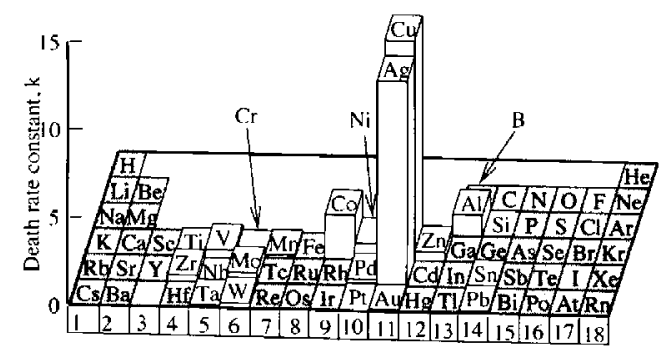

(a)

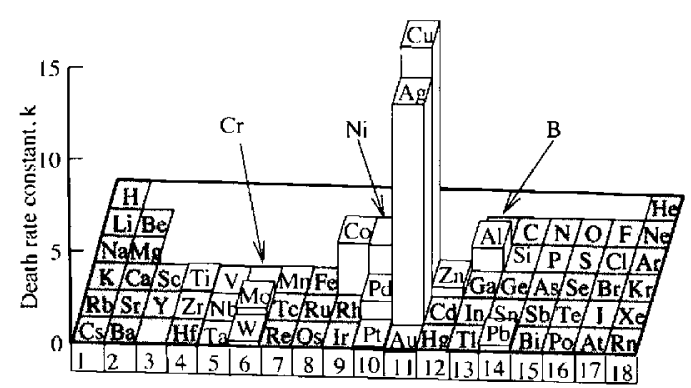

(b)

Fig. 4 Deth rate constant .

(a) Staphylococcus aureus

(b) Esherichia coli Elements not tested are hashed.

菌数の減少曲線の勾配の最大值を死滅速度定数として示し ており、白色の金属元素について試験を行っている。銅、 銀、コバルト、アルミニウム、ニッケル、亜鉛、パラジウム、 モリブデン㧍よびタングステンには抗菌性が認められた。 一方、シリコン、チタン、クロム、マンガン、スズ、タン タルおよび金については抗菌性は認められなかった。また、 白金技よび鉛は大腸菌についてのみ抗菌性を示し、バナジ ウム㧍よびジルコニウムは黄色ブドウ球菌についてのみ抗 菌性を示すことを示している。

Fig.5 は、JIS 法により試験した後の黄色ブドウ球菌を透 過型電子顕微鏡 (TEM) で観察した結果 ${ }^{8}$ である。Fig. 5 (a) は対照のものであり、球状で細胞膜は 2 重の明瞭な輪郭が

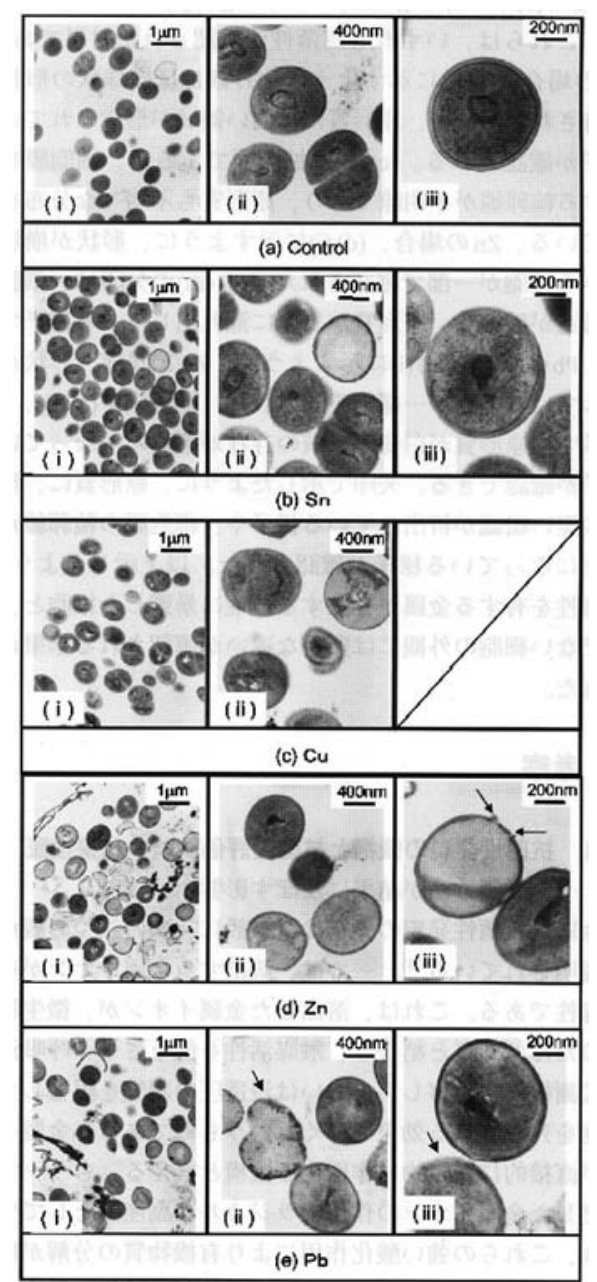

Fig. 5 TEM micro-photograph of the shape of Staphylococcus aureus after film contact method.

確認される。細胞の中央部には核が鮮明に確認され、原形 質が細胞膜内部に均一に分布しており、正常な状態の細胞 の外観と判断される。Fig. 5(b) は抗菌性が確認されない久 ズの観察結果である。外観は対照のものとほぼ同様である。

Fig. 5 (c) に銅、Fig. 5 (d) に亜鉛、Fig. 5(e) に鉛の結果を示 す。これらは、いずれも抗菌性が確認された金属である。 銅では (c) (i) のように外観はほぼ球状の形状が維持されて いるが、原形質には白い領域が確認され、(c) (ii) に見られ るように、細胞膜を形成する輪郭線が不明瞭であり、原形 質も不均一な分布を示してる。亜鉛では(d)(i)のように、 形状が崩壊している細胞が一部で確認される。(d) (iii)の 矢印は、細胞膜構造が破壊し、原形質が外部に漏れ出して いる。鉛では、(e) (i) のように、形状が崩壊している細胞 が一部で確認され、(e) (ii) や (iii) では原形質が白変し核の 存在が不鮮明になっており、矢印で示す箇所では原形質に 斑点状の黒い組織が観察され、細胞膜の輪郭線が不鮮明に なっている様子が観察される。このように、抗菌性が有る 


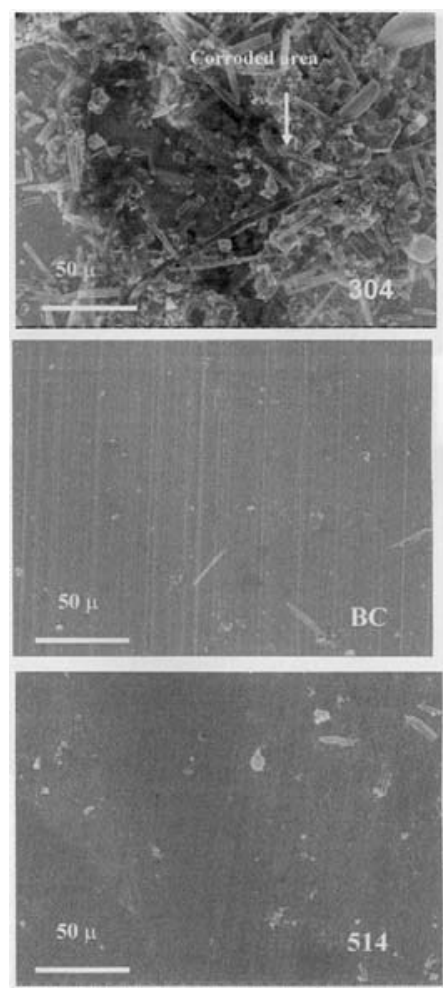

Fig.6 E-SEM images showing microfouling on different coupon surfaces exposed to a freshwater pound for 4 weeks.

金属とそうでない金属に微生物を接触させることにより、 細胞に及ぼす影響が異なることは興味有る結果であり、抗 菌作用の解明に役立つものと考えられる。

\section{3. 金属材料の抗菌性とバイオフィルム}

金属材料を腐食させる微生物腐食や配管内等で病原性の 微生物が増殖して害を及ぼす場合には、金属表面にバイオ フィルムが生成・発達することが条件になると言われてい る。我々の身の回りでの環境では、水と接する材料表面に 各種の物質が吸着しており、このような表面に微生物が付 着し、増殖過程で細胞外多糖を生産して自らの生活環境を 整える。ここに多様な微生物が高密度に棲息して発達して いるのがバイオフィルムであり、フィルムと言っても薄っ ペらものではなく、3 次元的構造を有していると考えられ ている ${ }^{10)}$ 。ここで、金属表面に生成するバイオフィルムに ついて少し考えることにする。

抗菌性の材料とそうでない材料とで微生物の付着やバイ オフィルムの生成・発達に違いがあるのか興味有る処であ るが、これらの点について幾つかの報告 ${ }^{11,12)}$ がある。銀 や銅を添加して抗菌化したステンレス鋼と通常のステンレ ス鋼を微生物を培養した菌液中に浸漬した後、表面を観察 すると通常のステンレス鋼には全面にバイオフィルムが生 成・発達しているのに対して抗菌化ステンレス鋼では菌の 付着が観察されるもののバイオフィルムの生成・発達が著

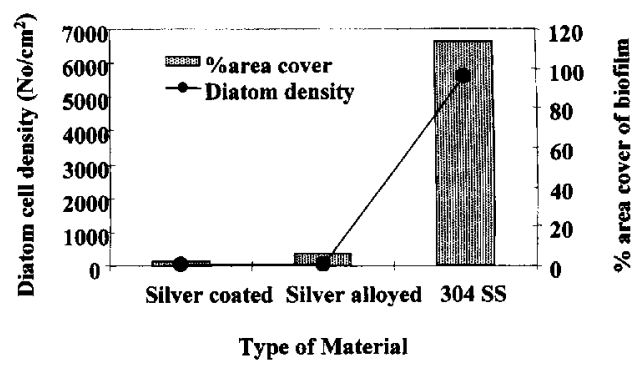

Fig.7 Diatom cell density and percentage area cover of biofilm over different coupons exposed to a freshwaterfield for 30 days.
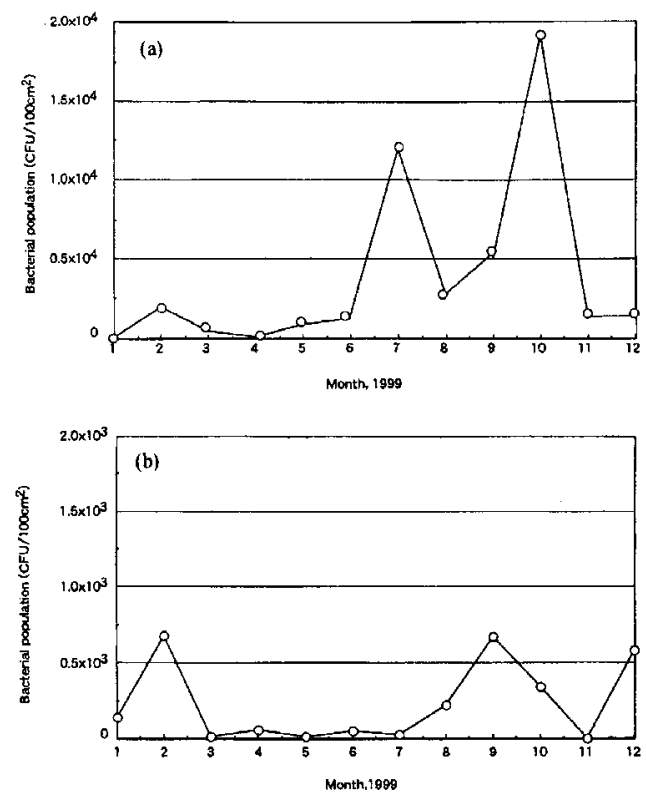

Fig. 8 Monthly change of bacterial population on material surfaces environment.

(a) SUS 304 stainless steel

(b) Antibacterial plating stainless steel

しく抑制された実験結果 ${ }^{11)}$ が報告されている。また、フィー ルド実験として抗菌化ステンレス鋼と通常のステンレス鋼 を池の中の水深 $0.5 \mathrm{~m}$ の位置に 28 日間浸漬して表面を観察 した結果 ${ }^{12}$ をFig. 6 に示す。通常の 304 型ステンレス鋼 (304 と表示）では表面に珪藻類、細菌類およびその他の付着物 が多数観察されるのに対して、銀コーティングステンレス 鋼（BC と表示）および銀を 0.039mass\% 添加した銀添加ス テンレス鋼（514 と表示）表面には、それらがほとんど観 察されなかった。この結果を定量化したのが Fig. $7^{12)}$ であ る。この他にも、日常環境において抗菌化ステンレス鋼へ の微生物付着やバイオフィルム生成・発達の抑制効果が試 験 ${ }^{13,14)}$ されている。Fig. 8 は、100人規模の給食製造設備 における厨房内調理台脚部の細菌数の変化を 1 年間に亘り 調べた結果 ${ }^{13)}$ である。Fig. 8 (a) は通常の 304 型ステンレ ス鋼脚部の結果であり、Fig. 8 (b) は抗菌メッキを施したス 
テンレス鋼脚部の結果である。抗菌処理を施すことにより、 細菌数が $1 / 10$ 以下に減少して扮り、優れた抗菌効果を発揮 していることがわかる。

このように材料の抗菌化は、微生物の付着やバイオフィ ルムの生成・発達の抑制に一定以上の効果があると考えら る。しかし、この抑制作用も時間経過とともに低下すると いう指摘や初期付着にはあまり関係しないがバイオフィル ムの発達に影響を及ぼすとの考えもあるようだ。いずれも 今後の検討課題と考えられる。

\section{4. まとめ}

金属材料の研究においても抗菌性やバイオフィルムは、 新しい切り口ではないだろうか。微生物などというと、我々 材料学の側の研究者には何か取っ付き難い印象を与える が、生物系の研究者にとっても金属材料などは親しめない 無味乾燥なシロモノのようである。しかし、この分野の研 究は、材料学にとっても生物学にとっても重要な研究分野 になっていくように思われる。

また、金属材料の抗菌機能化は、材料の適用範囲に大き な拡がりを持つ可能性を秘めている。小さいものでは、例 えば歯科用材料の抗菌機能化が考えられるし、大きなもの では微生物腐食軽減の観点からダムの水門、水処理施設や 工場施設の配管等における構造材料の抗菌機能化が考えら れる。しかも金属材料の抗菌機能化という視点では、日本 が世界をリードしている分野の一つでもある。日本の材料 学研究のパワーと生物系研究者がタッグを組めば、「抗菌機 能化金属材料」という日本発の世界ブランドを創り上げる ことも夢ではないと考えられる。今後、日本が環境分野の 技術で世界に貢献する場合にも金属材料の抗菌機能化は一
つの大きなツールになるだろうと考えられる。金属材料の 抗菌機能化の研究は、緒に就いたばかりである。今後この 分野の研究が、色々な研究分野の方々の熱意と協力により 発展することを切望し、終わりとする。

\section{参考文献}

1) JIS Z 2801、抗菌加工製品一抗菌性試験方法 - 抗菌効果 (2000).

2) 天谷尚：ふえらむ、12 (2007) 6, 347-352.

3) D. W. Walsh: Corrosion 99, NACE International, Houston (1999), Paper No.188.

4) K. R. Sreekmari, Y. Sato and Y.Kikuchi: Mate. Trans., 46(2005)7, 1636-1645.

5）山本玲子：まてりあ、43(2004) 8，639-642.

6）誰でもわかる抗菌の基礎知識、西村民雄監修、テクノシステム、 東京、(1999), 143.

7）横田毅、栃原美佐子、高尾研治、佐藤進、山下英明：まてりあ、 40 (2001) 1, 85-87.

8）宮野泰征、小山訓裕、K. R. スリクマリー、佐藤嘉洋、菊地靖志: 鉄と鋼、93 (2007) 1， 57-65.

9) H.Kawakami, K.Yoshida, Y.Nishida, Y.Kikuchi and Y. Sato: ISIJ Intern., 48 (2008) 9, 1299-1304.

10）森崎久雄：ふえらむ、12 (2007) 4, 191-198,

11）菊地靖志：ふえらむ、12 (2007) 5，275-281.

12) K. R. Sreekmari, K. Nandakumar, K. Takao and Y.Kikuchi: ISIJ Intern., 43 (2003) 11, 1799-1806.

13）山田貞子、漆原亘、中山武典：防菌防徽、29 (2001) 12, $763-$ 768.

14）鈴木聡、塩川光一郎、平松直人：防菌防徽、29 (2001) 7, 433444. 